\title{
Correction to: Heat and mass transfer in activated carbon composites with artificial macro pores for heat pump applications
}

\author{
Oliver Kraft ${ }^{1}$ [ $\cdot$ Matthias Stripf ${ }^{1} \cdot$ Ullrich Hesse $^{2}$
}

Published online: 30 July 2019

○) Springer Science+Business Media, LLC, part of Springer Nature 2019

\section{Correction to: Adsorption}

https://doi.org/10.1007/s10450-019-00077-7

The original version of the article unfortunately contained mistakes in author names. The authors' given names and family names were transposed.

The correct and complete names of the authors are as follows:

Oliver Kraft, Matthias Stripf, Ullrich Hesse

The original article has been corrected.

Publisher's Note Springer Nature remains neutral with regard to jurisdictional claims in published maps and institutional affiliations.

The original article can be found online at https://doi.org/10.1007/ s10450-019-00077-7.

$\triangle$ Oliver Kraft

Oliver.Kraft@hs-karlsruhe.de

Matthias Stripf

Matthias.Stripf@hs-karlsruhe.de

1 Karlsruhe University of Applied Sciences, Moltkestr. 30,

76133 Karlsruhe, Germany

2 Institute of Power Engineering, Technical University Dresden, Helmholtzstr. 10, 01069 Dresden, Germany 